\title{
Subsurface Geological and Hydrogeological Conditions of the Matale District, Sri Lanka: Inferred from Vertical Electrical Sounding Curves
}

\author{
C.N. Nupearachchi ${ }^{1}$, K.M.Prematilaka ${ }^{2}$, A.N.B.Attanayake ${ }^{3}$, \\ G.W.A.R.Fernando ${ }^{4}$. \\ chathunilnupe@gmail.com, mahinda163@yahoo.com \\ attanayake@uwu.ac.lk,gwfer@ou.ac.lk
}

\begin{abstract}
The electrical resistivity method which has important applications in mineral resources and groundwater exploration is used to map variations in the electrical properties of the subsurface. The study area, the District of Matale forms a part of the Central Province of Sri Lanka. The major rock types of the area consist of crystalline limestone, garnet-sillimanite gneiss, charnockitic gneiss and quartzite. Fifteen vertical electrical soundings (VES) were carried out in the Matale District using the Schlumberger configuration. Initially, fifteen apparent resistivity field curves were analyzed manually. Subsequently IPI2WIN open source software was used for computational interpretation. The VES points were located mainly in three lithologies; quartzite, crystalline limestone and gneiss. Electrical conductivity of groundwater in the region was found to be uniform and had no significant salinity-based impact on the resistivity variations. The majority of resistivity layers obtained from the VES correlated with the drill logs of same points indicating a considerable degree of relevance for their application as a tool to investigate subsurface geological and hydrogeological conditions. Introduction
\end{abstract}

The Direct Current (DC) resistivity method is used to measure the electrical resistivity of a geological section which includes soil, rock and groundwater. Accordingly, the method may be used to assess the lateral changes in the physical properties of the vertical cross sections of the natural geological settings. DC resistivity techniques measure the Earth's resistivity by applying a DC signal into the ground through a pair of surface electrodes. The resulting potential differences (voltages) are measured at the surface between a second pair of electrodes. The subsurface resistivity can be calculated by knowing the electrode separation, geometry of the electrode configuration, applied current and measured voltage. Thus from obtained data, the electrical properties of the Earth (the geo-electrical section) can be derived. Resistivity methods are most commonly used for the identification of the water table (Lowrie, 1997). The method is also extensively used to 
Subsurface Geological and Hydrogeological Conditions of the Matale District, Sri Lanka: Inferred from Vertical Electrical Sounding Curves

assess groundwater resources in subsurface geological formations.

The resistivity technique can be used for horizontal profiling or vertical sounding. Profiling provides a means of mapping lateral changes in subsurface electrical properties and identifying near-vertical features such as fracture zones. Sounding provides a means of determining the vertical changes in subsurface electrical properties which can be interpreted to obtain quantitative parameters such as depth from surface to saline groundwater body. There are several possible electrode arrangements. The two most popular electrode configurations in VES are the Schlumberger and the Wenner configurations (Figure 1) where $\mathrm{A}$ and $\mathrm{V}$ are applied currents and measured voltages respectively. $\mathrm{C} 1$ and $\mathrm{C} 2$ are the current electrodes whereas $\mathrm{P} 1$ and $\mathrm{P} 2$ are potential electrodes. $\mathrm{L}$ and a are electrode spacing.

Figure 1. Electrode arrangements in Wenner (X) and Schlumberger (Y) configurations
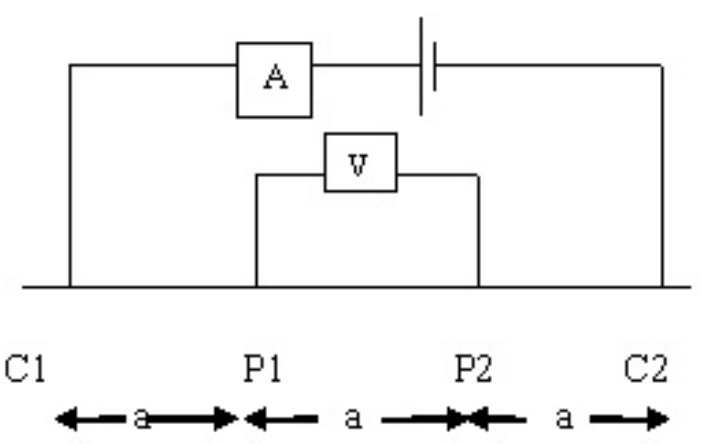

X

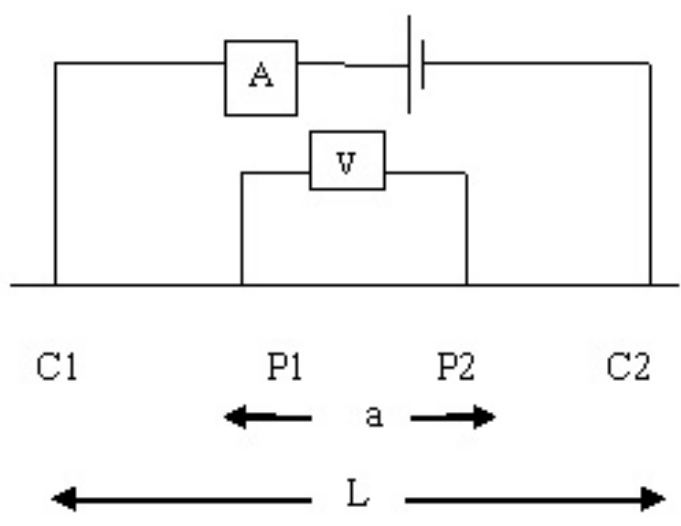

Y 
The Schlumberger arrangement offers the important advantage of being less sensitive to unknown lateral inhomogeneities because the potential electrodes remain in a fixed position during a large number of successive measurements. Field work can also be carried out rapidly.

The end product from a resistivity survey is generally a geo-electric cross section showing thicknesses and resistivities of currentpenetrated subsurface geo-electric layers. If borehole data or a conceptual geologic model is available, then a geological identity can be assigned to them.

The objective of the present study was mainly to compare the interpreted computational data of the resistivity soundings with general geological and hydrogeological conditions observed in the water supply boreholes in the study area.

\section{Study Area}

The Matale District which is situated in the Central Province of Sri Lanka is an agricultural area, dominated by tea, rubber, vegetable and spice cultivation and home gardens.

The study area consists mainly of high-grade metamorphic rocks belonging to the Highland Complex and post tectonic pegmatites. (Cooray, 1984) The major rock types of the area include crystalline limestone, garnet-sillimanite gneiss, charnockitic gneiss and quartzite. All major rocks show a general strike trend of NW- SE. The compositional layering is the prominent ductile structural feature in the rocks while large-scale upright folds are present in the middle and western parts of the area. Two sets of brittle fractures with fairly high intensity are also present trending NNW-SSE and E-W directions.

The Matale District being a crystalline basement complex possesses hydrogeological conditions similar to that of many hard rock areas of other tropical regions in the world. Groundwater in the district occurs mainly in association with alluvial sediments, regolith of the basement rocks and within the bedrock, in zones of secondary porosity such as joints, faults, fractures, fissures or in solution cavities. (Christensen \& Dharmagunawardhane, 1986) 
Subsurface Geological and Hydrogeological Conditions of the Matale District, Sri Lanka: Inferred from Vertical Electrical Sounding Curves

\section{Methodology}

In this research study, results of 15 vertical electrical soundings of the Schlumberger arrangement were used.

The interpretation of resistivity sounding data was done in two stages. As the first step, the apparent resistivity curves were analyzed using combined master curve matching and auxiliary point diagrams (Orellana \& Mooney, 1966). Secondly, the open source software IPI2WIN (version 3.0.1 developed by Department of Geophysics, Geological Faculty, Moscow State University \& Geo Scan-M Ltd, Moscow, Russia) was used for computer-aided interpretation. The different layers thus obtained from the interpretation of curves from both methods for each location were compared with the actual situation obtained from the boreholes data. A statistical geological correlation was done using computer interpreted resistivity data and borehole data making use of the statistical software; Minitab. (version 15 developed by Minitab Inc., USA)

\section{Results and Discussion}

The locations of the VES points are shown in Figure 2. In the studied 15 curves (Figure 3 and 4), three distinct resistivity layers became evident. The first layer (uppermost surface layer) showed a comparatively low resistivity range with an average value of $336 \Omega \mathrm{m}$. The second layer showed a moderate resistivity range with an average value of $1222 \Omega \mathrm{m}$. The resistivity range of the third layer was very high and it varied up to $70000 \Omega \mathrm{m}$. The resistivity variation of geo-electrical layers can be attributed to the variation of subsurface conditions such as the composition, moisture or the presence of water, the degree of weathering and the presence of discontinuities in rocks.

In drill logs too, three distinct compositional layers could be observed as top soil, slightly to moderately weathered regolith and the fractured or unfractured fresh rock. The thickness of the top soil layer was much less than that of the other two layers. These three layers showed different penetration rates during drilling, indicating their different physical strengths against cutting by the drilling tool. The average penetration rates during drilling in top soil and the regolith layer were $3.0 \mathrm{~min} / \mathrm{m}$ and $4.8 \mathrm{~min} / \mathrm{m}$ respectively. The underlying rock layer gave a comparatively higher average penetration rate of $5.8 \mathrm{~min} / \mathrm{m}$. 
A comparison of layers in the drill logs $(\mathrm{BH})$ and the thickness of layers inferred from the geo-electrical soundings (VES) are shown in the Table 1.

Some of the VES curves (VES 05, VES 06, VES 07 and VES 14) were smoothed into representing three layers for easy interpretation. This caused slight inconsistency in the predicted and the observed thickness of the second layer.

Geologically, the VES points were located mainly in three rock types: quartzite; crystalline limestone; and gneisses. The resistivity variation of these three rock types is shown in Table 2. It was noted that the majority of the resistivity layers interpreted from the VES, especially in the regolith layer correlated with the drill logs. A positive Pearson's correlation coefficient of 0.857 was found for the regolith layer. Figure 5 shows the correlation of VES (VES_R) and the thickness of regolith in the bore hole (BH_R). It was also noted that the thickness of the top soil in the bore hole logs was marked mostly as $1.5 \mathrm{~m}$. In general, drillers enter the length of the first drilling rod as the thickness of the top soil in logs. Since this is only an approximation and not a true value of the actual situation, it was not possible to correlate the sounding data correctly with the actual thickness of the top soil layer. 
Subsurface Geological and Hydrogeological Conditions of the Matale District, Sri Lanka: Inferred from Vertical Electrical Sounding Curves

Figure 2. Simplified structural map showing locations of VES points in the Matale District

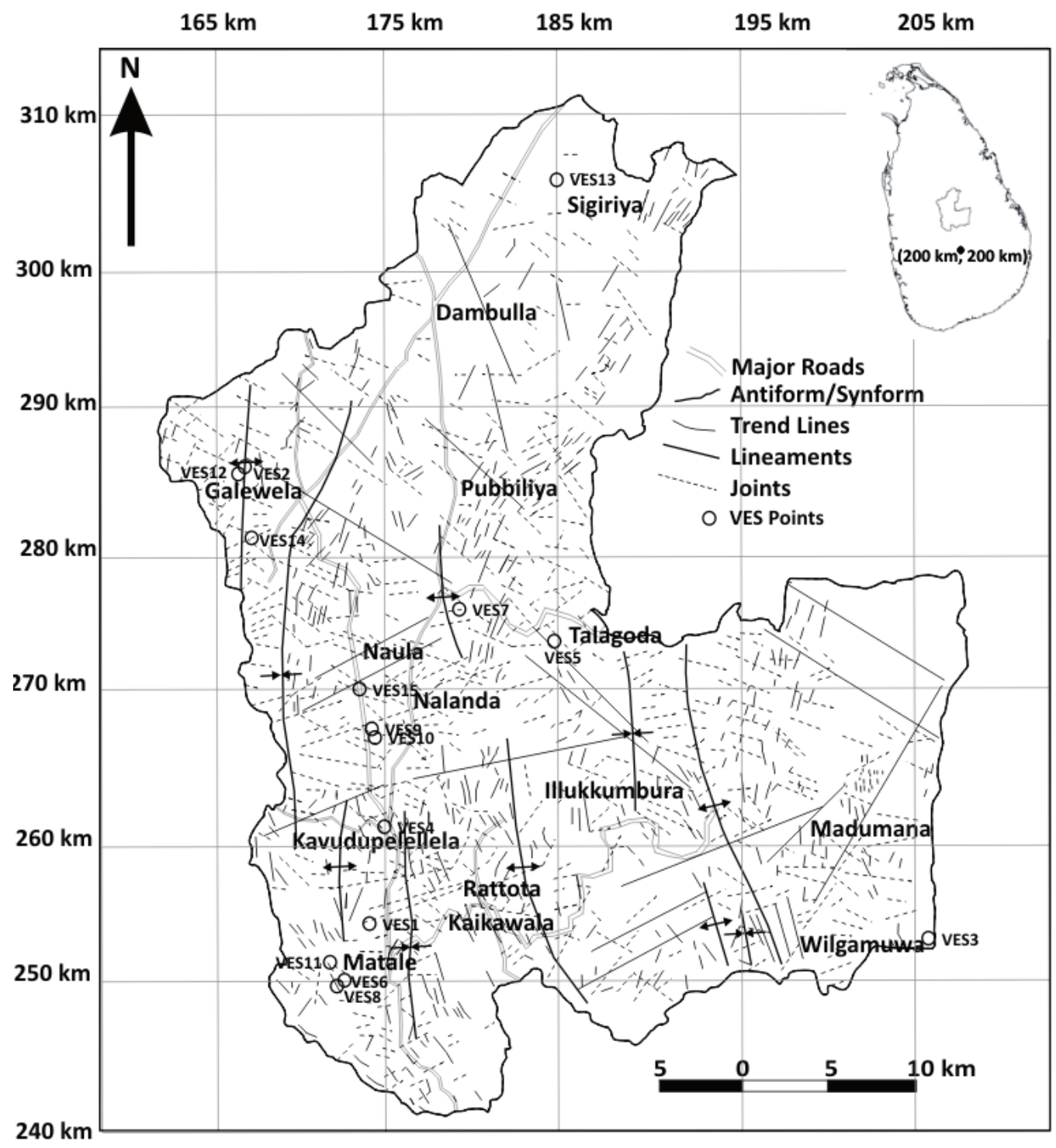


Figure 3. Vertical Electrical Sounding Curves VES 01 to VES 07

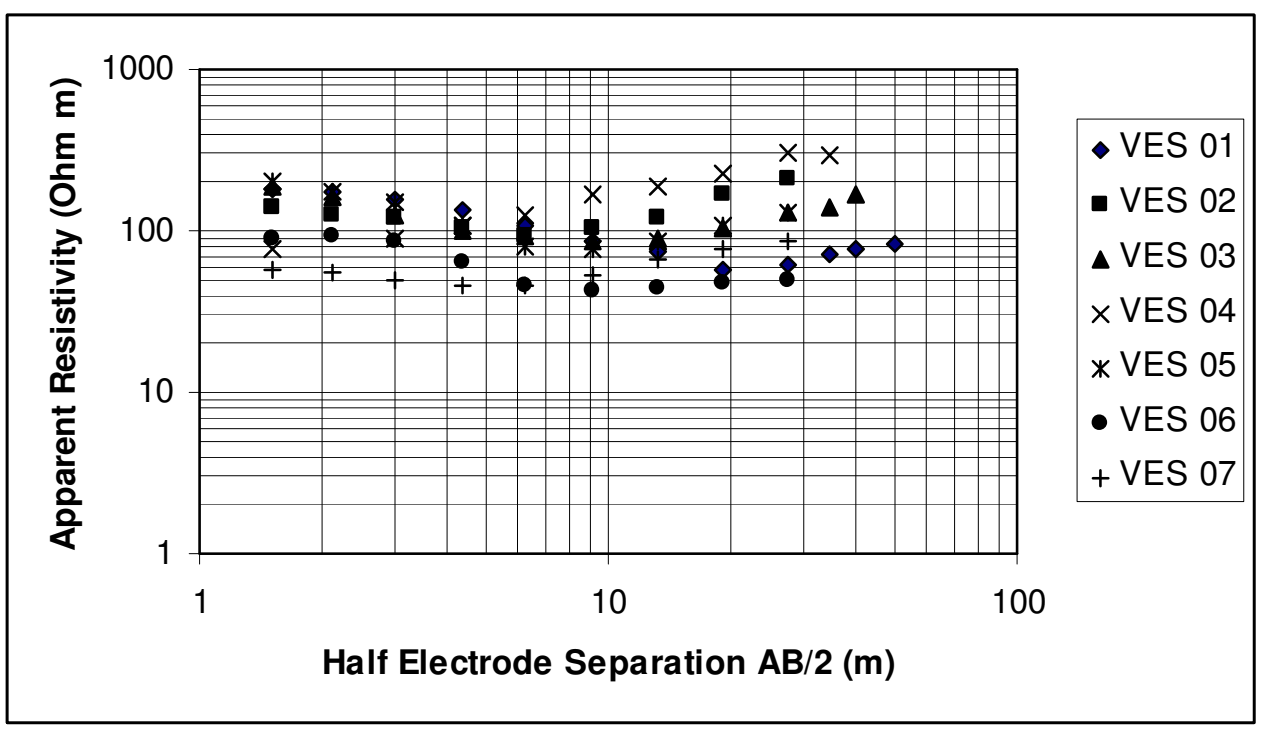

Figure 4. Vertical Electrical Sounding Curves VES 08 to VES 15

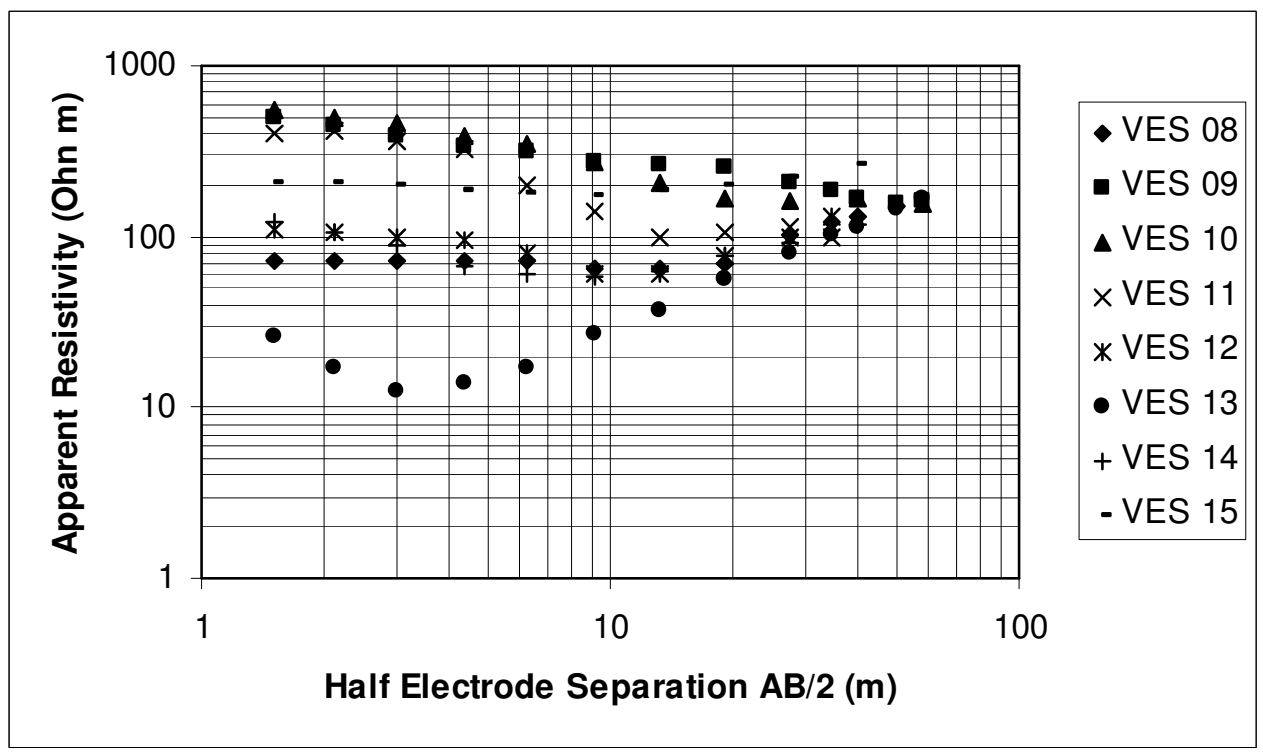


Subsurface Geological and Hydrogeological Conditions of the Matale District, Sri Lanka: Inferred from Vertical Electrical Sounding Curves

Figure 5. Correlation of the thickness of the regolith obtained from VES and borehole data

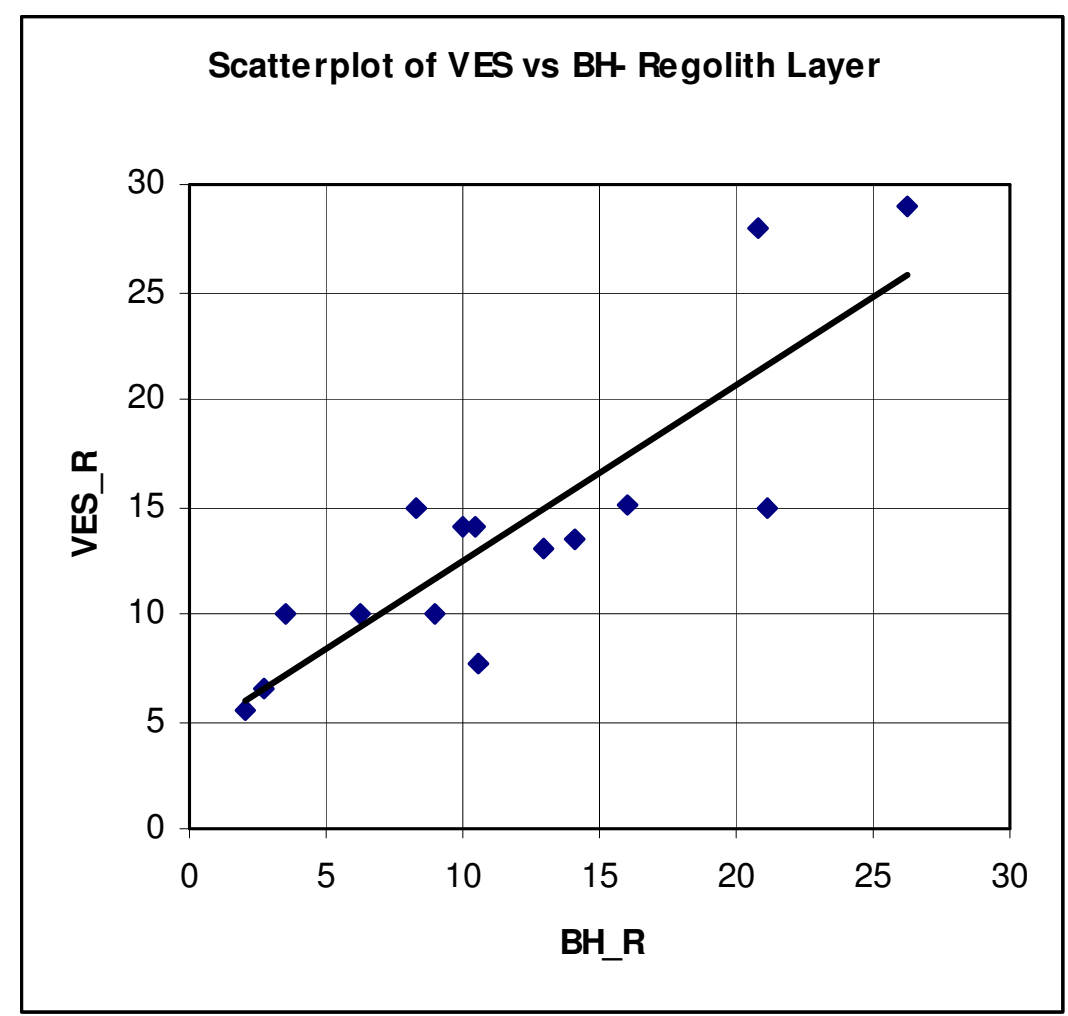

The quartzite rocks showed the highest average resistivity values in the top soil $(577 \Omega \mathrm{m})$ and the regolith layer $(3252 \Omega \mathrm{m})$ compared to the other two rock types. The average low resistivity values from the top soil $(161 \Omega \mathrm{m})$ and the regolith layer $(79 \Omega \mathrm{m})$ were recorded in the biotite gneisses and the charnockitic gneisses. The average resistivity of the regolith layer in the gneissic rocks was less than that of the top soil layer mainly because of the water content in the regolith of that rock type. A very high resistivity range in the fractured/unfractured fresh rock layer was observed in gneiss $(70000 \Omega \mathrm{m})$ and crystalline limestone (6600 $\Omega \mathrm{m}$ ). Less representative amount of information was available on average resistivity of quartzite and hence its resistivity range was not considered. The majority of the low to moderate resistivity values (less than $300 \Omega \mathrm{m}$ ) within the regolith or bed rock was an indication for favourable groundwater conditions (VES 02, VES 03, VES 04, VES 05, VES 06, VES 07, VES 08, VES 09, VES 10, VES 
11 , VES 12, VES 14 and VES 15) and the hydrogeological conditions and bore hole information are summarized in Table 3.

It was noted that low resistivity values in the rock layer inferred from some VES (VES 1 and VES 11) indicated favorable conditions for high yields. However, the bore hole data of the same locations showed only poor water yields. In addition, very high resistivity values in the rock inferred from VES 13, indicative of almost non-permeable rock showed comparatively good groundwater yielding conditions.

Table 1. The comparison of layer thicknesses deduced from VES with borehole logs

\begin{tabular}{|c|c|c|c|c|}
\hline $\begin{array}{c}\text { VES } \\
\text { no. }\end{array}$ & \multicolumn{2}{|l|}{ depth of top soil (m) } & \multicolumn{2}{l|}{ regolith layer (m) } \\
\hline & VES & BH & VES & BH \\
\hline 1 & 3.43 & 1.50 & 21.10 & 15.00 \\
\hline 2 & 2.07 & 1.50 & 6.28 & 10.00 \\
\hline 3 & 1.15 & 1.50 & 10.40 & 14.00 \\
\hline 4 & 4.18 & 1.30 & 10.60 & 7.70 \\
\hline 5 & 1.79 & 1.50 & 3.57 & 10.00 \\
\hline 6 & 2.18 & 1.50 & 10.00 & 14.00 \\
\hline 7 & 1.57 & 1.50 & 2.70 & 6.50 \\
\hline 8 & 3.87 & 1.50 & 13.00 & 13.00 \\
\hline 9 & 2.67 & 1.50 & 26.30 & 29.00 \\
\hline 10 & 3.15 & 1.50 & 20.80 & 28.00 \\
\hline 11 & 2.74 & 1.50 & 16.00 & 15.10 \\
\hline 12 & 3.04 & 1.50 & 9.00 & 10.00 \\
\hline 13 & 0.79 & 1.50 & 2.10 & 5.50 \\
\hline 14 & 1.18 & 1.50 & 8.34 & 15.00 \\
\hline 15 & 1.96 & 1.50 & 14.10 & 13.50 \\
\hline
\end{tabular}


Subsurface Geological and Hydrogeological Conditions of the Matale District, Sri Lanka: Inferred from Vertical Electrical Sounding Curves

The electrical conductivity measurements of water were available in some bore holes. It was observed that, impact of salinity was not evident for the variation of layer resistivity in the study area.

According to Dharmagunawardhane and Ajith Prema (1994), the presence of conducting minerals such as graphite, pyrite and magnetite in rocks and the regolith under favorable conditions may lead to low formation resistivity estimates that cannot be attributed to a particular groundwater condition. Therefore, VES curves at such sites may be misinterpreted as indicative of layers of marked groundwater potential in depths.

Table 2. The resistivity values of different weathering states of the three major rock types of the study area

\begin{tabular}{|c|c|c|c|c|c|}
\hline \multirow{2}{*}{ rock type } & \multicolumn{2}{|c|}{ top soil } & \multicolumn{2}{|c|}{ regolith layer } & \multirow{2}{*}{$\begin{array}{c}\text { fractured/unfractured } \\
\text { fresh rock layer } \\
\text { values } \\
(\Omega \mathrm{m})\end{array}$} \\
\hline & $\begin{array}{l}\text { range } \\
(\Omega \mathrm{m})\end{array}$ & $\begin{array}{c}\text { average } \\
(\Omega \mathrm{m})\end{array}$ & $\begin{array}{l}\text { range } \\
(\Omega \mathrm{m})\end{array}$ & $\begin{array}{c}\text { average } \\
(\Omega \mathrm{m})\end{array}$ & \\
\hline Quartzite & $\begin{array}{l}150- \\
1370\end{array}$ & 577 & $\begin{array}{l}160- \\
9400\end{array}$ & 3252 & $450<$ \\
\hline $\begin{array}{l}\text { Crystalline } \\
\text { Limestone }\end{array}$ & $\begin{array}{l}40- \\
640\end{array}$ & 270 & $\begin{array}{c}4- \\
2050\end{array}$ & 334 & up to 6600 \\
\hline Gneiss & $\begin{array}{l}21- \\
260\end{array}$ & 161 & $\begin{array}{l}17- \\
260\end{array}$ & 79 & up to 70000 \\
\hline
\end{tabular}


Table 3. The summarized hydrogeological conditions and bore hole details

\begin{tabular}{|c|c|c|c|c|c|c|}
\hline $\begin{array}{l}\text { VES } \\
\text { num }\end{array}$ & $\operatorname{depth}(m)$ & overburden depth $(\mathrm{m})$ & $\begin{array}{l}\text { yield } \\
(\mathrm{lpm})\end{array}$ & $\begin{array}{l}\text { groundwater } \\
\text { conductivity } \\
(\mu \mathrm{S} / \mathrm{cm})\end{array}$ & $\begin{array}{l}\text { depth to water } \\
\text { bearing } \\
\text { formation below } \\
\text { ground level(m) }\end{array}$ & rock type \\
\hline 1 & 90.5 & 15 & 0 & $\mathrm{n} . \mathrm{m}$ & - & crystalline limestone \\
\hline 2 & 31 & 9.5 & 30 & 335 & $9,11.2,19.5$ & gneiss \\
\hline 3 & 37.5 & 14 & 30 & n.m & $16,18,21$ & gneiss \\
\hline 4 & 27 & 7.7 & 135 & 670 & $12,18,23$ & crystalline limestone \\
\hline 5 & 46 & 10 & 50 & n.m & $17.5,18,38$ & gneiss \\
\hline 6 & 15 & 14 & 100 & $\mathrm{n} . \mathrm{m}$ & 15 & crystalline limestone \\
\hline 7 & 31 & 6.5 & 100 & n.m & $11.3,14,18.5,30$ & gneiss \\
\hline 8 & 24 & 13 & 60 & n.m & $12.5,20,24$ & crystalline limestone \\
\hline 9 & 43.5 & 30 & $2000<$ & 600 & $\begin{array}{c}29,30- \\
32,34.5,35.5\end{array}$ & crystalline limestone \\
\hline 10 & 39 & 28 & 1500 & 400 & $21,28,35$ & crystalline limestone \\
\hline 11 & 67.5 & 18.2 & 6 & 420 & $21,52.5$ & crystalline limestone \\
\hline 12 & 42 & 11.5 & 18 & 790 & $20.5,29$ & gneiss \\
\hline 13 & 36 & 5.5 & 60 & 1432 & $12.8,27.6$ & crystalline limestone \\
\hline 14 & 31 & 17 & 16 & 462 & $17,23,25.5$ & gneiss \\
\hline 15 & 34 & 14 & 50 & n.m & 22,25 & quartzite \\
\hline
\end{tabular}

n.m $=$ not measured 
Subsurface Geological and Hydrogeological Conditions of the Matale District, Sri Lanka: Inferred from Vertical Electrical Sounding Curves

\section{Conclusions}

The vertical electrical sounding interpretations provide reasonably accurate estimates on the depths of the different compositional horizons encountered in bore holes. Thus, the method used provides an efficient tool for groundwater studies in hard rock terrains. The reliability of VES relies on careful interpretation and integration of the results with other available geological and hydrogeological data from the sites to maintain a good success rate in well drilling in such areas.

\section{References}

Christensen, H. \& Dharmagunawardhane, H.A. (1986). Behaviour of Some Chemical Parameters in Tube Well Water in Matale and Polonnaruwa Districts. In C.B.Dissanayake \& L.Gunatilaka (Ed), Some Aspects of The Chemistry of The Environment of Sri Lanka (pp.25-43). Colombo, Sri Lanka: NARESA Printing Unit.

Cooray, P.G. (1984). An Introduction to the Geology of Sri Lanka (Ceylon). Colombo, Sri Lanka: Department of Government Printing.

Dharmagunawardhane, H.A \& Ajithprema, M.M.J.P. (1994). Resistivity surveys for groundwater investigation in hard rock areas of Sri Lanka. Journal of the Geological Society of Sri Lanka, 15, 113-120.

Lowrie, W. (1997). Fundamentals of Geophysics. Cambridge, England: Cambridge University Press

Orellana, M. \& Mooney, H.M. (1966), Master Tables and Curves for Vertical Sounding Over Layered Structures. Madrid, Spain: Interciencia 